\title{
“Only Strange Flowers Have Come to Bloom": Identity Crisis in Northeast India through the Poetry of Kynpham Sing Nongkynrih
}

\section{Neeraj Sankhyan}

\author{
Dr. Y. S. Parmar University of Horticulture and Forestry, Solan (HP), India
}

\section{Suman Sigroha}

Indian Institute of Technology (IIT) Mandi, (HP), India

\begin{abstract}
Socio-economic and political changes effected by modernization result in overlapping and muddling of various borders and boundaries, jeopardizing the very concept of a stable identity. Although traditional or essentialist identities have an innate momentum that has made them stand the test of time, conflicts between national and ethnic identities have often led to turmoil and violence, with the former trying to suppress the latter. This is particularly so in the North-eastern regions of India that suffer from an identity crisis owing to invasion by alien cultures, oppressive attitudes of the State aimed at forcefully homogenizing cultures that are essentially heterogeneous, and the adverse consequences of modernization; all of which have jeopardized indigenous cultures and identities. The literatures from these regions respond to these homogenizing tendencies with a strong voice of resistance. Kynpham Sing Nongkynrih is one such voice that blatantly disregards the mainstream poetics. Consequently, waning cultural values and imperiled ethnic identities remain chief concerns in his poetry. This paper analyses concerns related to causes and implications of identity crisis afflicting these people as reflected in Nongkynrih's poetry, while simultaneously positing it as a counter-culture tradition structured against the majoritarian discourse aiming to salvage a unique culture from an apparent identity crisis.
\end{abstract}

Keywords: Northeast India, Identity crisis, indigenous culture, modernization, ethnicity

\section{Introduction}

The modern Indian view considers the existence of different ethnic identities within the nation to be a source of conflict and thus holds ethno-cultural assimilation as the only solution to this conflict (Mukhim30). It is no wonder, then, that identity features as a major concern in the works of poets hailing from the North-eastern states of India. Imposition of a foreign religion (Christianity during the colonial times), a foreign culture (first British and then Indian) and a foreign rule (British before 1947 and Indian thereafter) along with the physical isolation of these people through "partially excluded and unadministered areas resulted in cultural isolation of the people from the rest of India ... [and formation of a] separate cultural identity" (Pakem16). Perceiving the influence and control of the Indian State authorities as a threat to their indigenous culture and traditional ways of life, the peoples of the region became suspicious of the former's presence, which gave rise to an atmosphere of distrust, conflict and turmoil. A feeling of threat to 
identity and culture gave rise to a false sense of nationalism which later manifested in the form of revolt against the Indian authorities and insurgency.

The term 'Northeast' is a misnomer used indifferently to misconstrue, as homogeneous, a heterogenous realm peopled by communities exhibiting myriads of disparate linguistic, ethnic and social identities, for the sake of political convenience and compromise. Commenting upon the vast diversity of cultures, peoples and languages that the entire North-East region is home to and its gross misrepresentation marked by homogeneity, the Shillong poets Robin Ngangom and Kynpham state:

Understandably, with a tenuous historical and geographical link to the rest of India, the North-East remains little known and perhaps largely misunderstood ... Its eight states ... are inhabited by such a conglomeration of peoples, a melange of cultures, languages and religions that it would be a grave injustice to make any generalized statement about them. (Ngangom and Nongkynrih Dancing Earth ix)

The apathetic view of the Indian government is made evident by its repressive policies that have been implemented since to suppress the unrest and turmoil, prominent among them being the implementation of the dreaded AFSPA (Armed Forces Special Powers Act of 1958) which gives the security forces unrestricted and unaccounted powers to execute security operations such as shooting, arresting and searching on the basis of mere suspicion in any area which the central government declares as disturbed. Besides, the security personnel have absolute immunity for their actions committed within the line of duty. The Act, ever since its imposition in 1958, has wrought havoc upon the lives of innocent civilians and resulted in innumerable atrocities. Highlighting the futility of AFSPA in containing the troubled situation, Grace Pelly argues:

Violence aimed at suppressing dissent has only increased under the draconian legislation, which has had the opposite effect than the purpose for which it was enacted. The hardship of civilian life under AFSPA and the impunity granted to the military under the Act only heighten the discontent of the population; this in turn fuels further militancy ... violence by military personnel breeds violence by the oppressed population. (Pelly and Singh 129)

Another factor leading to the identity crisis is the corrosive effect of globalization on the indigenous cultures and traditions that has resulted in a cultural uprooting as the indigenous culture is gradually replaced by the 
western. The emerging literatures from the region seek to reconstruct the traditions lost in the dust of times and to rework the fractured ethno-cultural identities by going back to the oral traditions and narratives of their respective tribes and communities. In order to counteract marginalization from mainstream socioliterary practices, writers from the region respond to the homogenizing tendencies of the mainstream with a strong voice of resistance asserting the unique identity of this region. Kynpham Sing Nongkynrih from Shillong, Meghalaya represents one such voice of dissent that endeavours to confront the concerns of the region by offering a counterpoint to the identity crisis and violence that is a part of everyday life of the people. This paper critically studies his poetry in the light of this identity crisis that plagues the entire region, and analyses how far his poetry, through a reworking of the literary and socio-cultural traditions of the region, manages to restore and vindicate a culture under threat of extinction.

Nongkynrih belongs to the Khasi ${ }^{1}$ tribe and writes poems and short fiction in both $\mathrm{Khasi}^{2}$ and English. Commenting on the politically charged poetry of Nongkynrih, Bhattacharjee and Guhacomment; "Nongkynrih assumes the role of a revisionist who recapitulates the identity-experience of the Northeast in the form of a politico-poetics that distinguishes him from the mainstream Indian English poets or even from the largesse of the Northeastern poets" (Bhattacharjee and Guha 83). Expounding the reasons for the apparent dissimilarity in the literary import of a writer from the North-eastern region of India from that of a writer from the Indian mainland, Nongkynrih and Ngangom in the Editors' Note to An Anthology of Contemporary Poetry from North-east India, argue that "while it may not make him a better writer, living with the menace of the gun he cannot merely indulge in verbal wizardry and woolly aesthetics but perforce master the art of witness" (Ngangom and Nongkynrih Anthology ix).

Drawing inspiration from political poets like "Pablo Neruda, Czeslaw Milosz, Mahmoud Darwish, and Yehuda Amichai who ... voice the anguish and aspirations of their land and its people" (Das 20), Nongkynrih feels obliged to write about the crucial contemporary problems that plague the Northeastern region which gives his "work a distinct identity within Indian English poetry but it also makes it different" (Das 20) and is probably the reason why in spite being an acclaimed and representative poet from the Northeastern region, Kynpham continues to be excluded "from contemporary anthologies that claim to represent Indian [English] poetry" (Das 19). This, however, does not deter him from writing politically charged poetry that gives vent to his ire and angst in response to political turmoil, oppression of the masses, violence, and erosion of tribal values and ethnic identity, lending his works a distinct poetic style. At the same time, Nongkynrih's poetry is a counter-culture tradition structured against the majoritarian discourse, that endeavours to salvage his unique culture from an apparent identity crisis and emphasizes his role as a witness to these waning cultural values. 
The notion of identity, often comprehended in terms of sameness or difference, has gone through numerous transformations in history. According to Robins, the concept of identity "centres on the assertion of principles of unity, as opposed to pluralism and diversity, and of continuity, as opposed to change and transformation" (Robins 172). Various socio-economic and political changes effected by modernization and globalization result in blurring, overlapping and muddling of various borders and boundaries jeopardizing the very concept of identity "when something assumed to be fixed, coherent and stable is displaced by the experience of doubt and uncertainty" (Mercer 259). This is especially true in the context of India's Northeast, an extreme borderland whose protruding shape on the Indian map is a consequence of drawing of arbitrary boundaries that dismembered the region across geographically and culturally conterminous lands, making it "the residual fallout of colonial politics and administration" (Phanjoubam 158). It was the fatal Partition of 1947, triggered by the idea of an exclusive homeland for South Asia's Muslims, that led to the creation of this isolated territory sandwiched among five countries, namely Bangladesh, Myanmar, Nepal, China, and Bhutan; it was "linked to the rest of India only by a narrow corridor between Nepal and EastPakistan / Bangladesh" (Van Schendel 32). However, the real predicament of the region arises not merely from its being a landlocked territory couched between five countries, but largely from the fact that the "... constituent states of the region are ... unable to connect ... physically ... and more seriously $\ldots$ intellectually and emotionally with their closest neighbours, or even with and among their own people" (Prabhakara 4606). The internal borders marking the domestic boundaries comprise crucial sites of contention due to assertion of heterogeneous ethnic identities since "they often reflect ethnic sentiments and notions of longing and belonging" (Tunyi and Wouters 3), thus making the region distinct from the rest of the country. The chief cause of the identity crisis that afflicts the region is a clashing and overlapping of the ethnic and political boundaries, the latter being largely arbitrary and inconsiderate of the former's interests and sensibilities.

This leads to social exclusion stemming from an inequitable distribution of opportunities, causing tension and conflict "between ethnic groups as a competition for rights, privileges, and available resources [and] ... between the state and the groups that dominate it on the one hand, and the populations that inhabit its territory on the other" (Brass 247). The exclusionary tendencies are further instigated when the process of construction of a national identity ignores the specificities of smaller communities, leading to eruption of ethnic separatist movements (Zariski 253-254) demanding ethnically exclusive homelands.

Homeland in such a context assumes complex connotations due to the association of 'home' with 'land' due to which its "geopolitical implications ... are far more concrete and corporeal than the emotional positionality of home. The term homeland, by recalling the connection to land also accentuates borders and boundaries" (Dutta 168). The presence of multiple identities as cultural, ethnic, linguistic, political etc. 
further complicates the identity issue, as a result of which contemporary identities seem to be in a constant state of flux with no single factor predominating. At the same time, traditional or essentialist identities have an innate momentum that has made them stand the test of time. The conflicts between national and ethnic identities have often led to turmoil and violence, with the former trying to suppress the latter forcefully. Homi Bhabha explains this dilemma in The Location of Culture:

[T]he very idea of a pure, 'ethnically cleansed' national identity can only be achieved through the death, literal and figurative, of the complex interweavings of history, and the culturally contingent borderlines of modern nationhood. This side of the psychosis of patriotic fervour, I like to think, there is overwhelming evidence of a more transnational and translational sense of the hybridity of imagined communities. (Bhabha 5)

With this background, the paper proceeds to take up the analysis of Kynpham's poetry with an aim to study concerns related to causes and implications of the identity crisis afflicting these people and to establish it as a counter-culture tradition structured against the majoritarian discourse, aiming to salvage a unique culture from an apparent identity crisis.

\section{Discussion}

In the poem titled "Only Strange Flowers Have Come to Bloom", Nongkynrih (6-8) talks about the identity threat posed by the influx of outsiders to the tribes. A seemingly innocuous reference to David Scott, the infamous conquistador who first brought pears to the Khasi Hills could easily be mistaken for a poem about flowers until the real meaning begins to emerge. The reference becomes meaningful in the context of the "strange flowers" metaphor which could almost be replaced by weeds in its connotation, referring to the non-tribal people whom he accuses of violating the tribals' personal space. What begins initially in a casual and easy-going manner turns trenchant, cynical and acerbic later:

In the park I saw

Those strange flowers again

that I have seen bossing around

courtyards and private gardens (15-18)

These lines with their multiple layered meanings depict the poet's angst and sarcasm at seeing only strangers "bossing" and "blooming" in the land, and turns even more bitter in the concluding triplet: 


\section{Like flowers, only strangers \\ strange ways have come \\ to bloom in this land. (19-21)}

As Jorn Rusen argues; "Identity is a matter of culture. Culture is the entire achievement of the human mind in interpreting and understanding the given world including oneself as living in this world and being a part of it" (Rusen144). The relation between identity and culture as evident from this definition also points to another important aspect of identity i.e. the collective identity. Polletta and Jasper define collective identity as "an individual's cognitive, moral and emotional connection with a broader community, category, practice, or institution" (Polletta and Jasper 285). This definition implies a relation an individual holds with his/her community or tribe, a relation that is highly valued as a source of identity for the individual. Nongkynrih asserts this cultural connection in identity formation and laments the loss of such a connection due to the influx of outsiders who have no connection with the land, the people or their traditional ways.

As explained by Rusen, "Identity is a matter of personal and social coherence and togetherness in the manifold relationship to the circumstances and conditions of life ... [it] is a cultural achievement of human relatedness. It keeps people together in their manifold relations to other people..." (Rusen 144). Such relatedness in the North-eastern region is increasingly under threat or completely lacking in contemporary times, and people are seen as "strange flowers" with their "strange ways". The poem sharply draws attention towards the menace of illegal immigrations in the tribal areas of the Northeast region, due to which the problems inflicting the region such as poverty, unemployment and struggle for shrinking resources have been aggravated manifold. The indigenous communities are growing wary of illegal immigration as they feel that this may "lead to loss of land[,] ... damage tribal culture [and] in due course of time, the illegal immigrants might even become an ethnic group" (Singh 31), thus subverting their cultural heritage. Commenting on the link between an apparent identity crisis in the Northeast region and the massive influx of migrants into the tribal areas, B.P. Singh claims:

... widespread identity crisis ... has been caused by the large-scale migration of population from outside the region ... and the total dependence of people on the land and the States' apparatus for a livelihood. ... the local population feel[s] outnumbered and swamped by people of different cultural origins. The failure of various sections of the migrant population to adapt themselves to the local 
language, customs and traditions has further accentuated the identity crisis.

(Singh 162)

"When the Prime Minister Visits Shillong the Bamboos Watch in Silence" (Nongkynrih 10-11) highlights the identity crisis and alienation of the people in the Northeast and locates its cause in the apathy of the central government and its politicians whose few visits are mere formalities. The poem is an example of a political satire written with an intention to ridicule the protagonist of the poem, the 'Prime Minister'. Using a sarcastic tone throughout, the poet conjures up imagery implicating apathy and superciliousness, and deploys similes and metaphors to bring home the point. The following lines from the poem illustrate this:

But he was a rumbling in the clouds

a prattle in the air.

And some say he came

Homing in like a missile

and left flying like an arrow.

In between?

Some say he dropped like a falling star

And sighted by few

disgruntled leaders. (11-20)

Referring to the leader's visit, the use of the phrase "some say" is telling because it draws attention towards the former's rushed visit and his limited interactions with people. His visit is targeted like a "homing missile" and he leaves as swiftly as an "arrow" does. The poem can also be interpreted as an allusion to the conflict between the Indian Government and the North-East region. The imagery of weapons, namely the missile and the arrow, could be taken to symbolize the Indian government's military action, imposition of AFSPA and related atrocities, and the region's insurgency. Besides, they reflect the disparate power equations that operate in the region; arrows could never equal the might of missiles and thus are sure to lose. Interestingly, the symbol of a "falling star" signifies the empty promises made to the region, wishes that have remained unfulfilled. Similarly, the expression "bamboos watch in silence" figures as a political trope and recurs throughout the text as a leitmotif depicting the indifference and ignorance of the Government officials about the real state of affairs in the region. Nongkynrih through this poem sends a hard-hitting message to the politicians and the governments who have turned a deaf ear to the problems that haunt the people. This neglect and lack of empathy in treating the concerns of the region, along with the prolonged 
imposition of the harsh anti-human rights AFSPA by the central government, has worsened the situation by adding to the identity crisis and perpetuating it by continuing the alienation of these people from the rest of the country. Commenting on the unfair treatment meted out to the indigenous people, V.K. Nuh in Peace in India's North-East: Meaning, Metaphor, and Method writes:

Today most of the entire Northeast India is in flames with the desire for selfdetermination ... Human dignity is often denied. Human Rights are violated much. Most of the states are politically restricted and one after another Black Laws are imposed. Thus, North East India people often feel misinterpreted, misunderstood and neglected. (Nuh135)

"Rain Song 2000" (Nongkynrih 38-40) laments the grim state of affairs in the region marked by violence, terrorism, corruption, and suicides; it also ridicules the politicians' cupidity. Employing pathetic fallacy, he depicts the apathy and callousness of the media and the government towards the plight of the region thus:

But these are no more than fillers:

so why is the sky weeping

a river of unseasonable tears?

Why is the wind shrieking night and day

And pines beating their chests in pain? (20-24)

The last verse comments on the displacement and uprooting of the indigenous religion and culture by the introduction of Christianity during colonial times and the forceful mass conversions that followed. These conversions resulted in an ethnic divide, which led to the identity crisis during contemporary times. Commenting on the adverse impact of Christianity on ethnicity in Northeast India, Falguni Rajkumar writes:

... the British administration gave permission to the Christian missionaries to convert the upland communities even though they advocated the preservation of the socio-cultural identity...[thus dividing] the people on religious lines between the lowland Hindus and the Christianised upland people. The 'divide' has geopolitically and socio-culturally polarized the entire region completely thereafter. (Rajkumar 11) 
The concluding lines of the poem, "Hindus have gored too many good Samaritans. / Christians have forced too many conversions" (29-30) are a reference to the conflicts that ensue when individuals from disparate ethnic groups are compulsively and unthinkingly forced to come in contact.

The poem titled "Hiraeth", which is a Welsh word for 'longing', attempts to reconstruct the lost identity of his tribe and village while lamenting the unfavourable changes brought about by time. It does so by deploying a mix of aural and visual imagery to make clear this distinction between the good old days and the turbulent present. Consequently, phrases like "morning sounds of home: birds warbling, cicada whining, crows cawing, chickens yapping about the yard..." (4-6) and "ghostly ancestors [...] warming up for their fields, boiling rice, packing their midday meal in leaves" (13-16) conjure up the resplendent past while "raucous azaans" ${ }^{3}$, jangling bells, wild ululations, weird conch shells, [...]spirituous carols, clamorous crackers ..." (24-27) relate to the tumultuous present. The poet by way of recalling the mellifluous natural sounds of yore and contrasting them with the cacophony of modern times mourns the waning Khasi musical traditions, which were heavily influenced by the "sounds of nature like that of a waterfall, bird calls, insect sounds, hum of bees and many more" (Bhatnagar "The tribal festivals of Meghalaya").

Though simplistic and lacking sophistication, Khasi music is made special by its incorporation of natural elements which lend it an ethereal beauty and purity and make it an indispensable part of every festival and ceremony from birth to death ("Festivals and Ceremonies of the "Khasis"'). However, the "strange sounds" (29) of the present times are turning this idyllic world "obsolete" (31) which is an unwelcome change to the poet's sensibilities. The poem is a comment on the increasing sense of bewilderment and alienation the poet feels in his land due to the changing sounds, which further aggravates the identity crisis by severing the ties that hold these tribes bonded to nature and the land. Similar concerns echo in the poem "Agartala Nights" (Nongkynrih 57-58) which talks of the lost grandeur of yesteryear that once marked the heritage town of Agartala, which today appears to the poet as a town of "grey dust and chaotic rickshaws, ... as from a book of fables" (2-3). Lamenting the pathetic fall of the town from its glorious past, the author can't help declaring such to be "the fate of all empty spaces" (21) which is what the word 'Agartala' conveys - an empty space. The title facetiously refers to the emptiness of both the town and the people, splintered from their living traditions as well as places that held cultural meanings. Replete with vivid imagery that evokes a realistic picture of the town, it mourns the loss of native traditions and customs and is critical of the conversion of palaces, symbols of cultural heritage, into public buildings and tourist destinations as suggested in the following lines: 
Supplant their customs, reduce their palaces

into lowly assembly houses and tourist destinations.

Herd them to the mainstream, drown them there. (10-12)

Converting a place into a tourist attraction leads to its objectification since it amounts to turning it into a product ready for consumption by some passive onlooker whose only interest lies in seeking personal gratification and sensual pleasure. The voyeuristic gaze is demeaning for it is essentially associated with the subjective point of view. Further, according to Greenwood, "local culture [...] is altered and often destroyed by the treatment of it as a touristic attraction. It is made meaningless to the people who once believed in it..." (Greenwood 131). Commenting on the commoditization of culture by tourism, Erik Cohen writes:

The critical issue is that commoditization allegedly changes the meaning of cultural products and of human relations, making them eventually meaningless [...]. As cultural products lose their meaning for the locals, and as the need to present the tourist with ever more spectacular, exotic and titillating attractions grows, contrived cultural products are increasingly 'staged' for tourists and decorated so as to look authentic. (Cohen 372)

The poem is a candid reflection of how disconcerted the poet is about the degradation and loss of this treasured cultural meaning, brought about by the invasion of an alien culture which, to quote the poet, is "the most effective way of silencing races" (6). Many of Nongkynrih's poems exhibit bioregional orientation and a strong sense of belonging to the milieu within which he endeavours to situate his sense of identity.

In "Kynshi" (Nongkynrih 43-45), the poet expresses his heartfelt concern and anxiety about the deteriorating state of the river Kynshi which once has bred "the truest Khasi braves" (4). By doing so, he underscores the river's significance as a prominent identity marker of the Khasi community and associates its contamination with the community's jeopardized identity. The poet laments the loss of greenery and defacing of the serene hills that has been brought about as a result of indiscriminate developmental activities fueled by a mad race for globalization. Another adverse effect of this has been the decline of the Tynnai ${ }^{4}$ cane craft, which was once a thriving industry and important symbol of the region's cultural heritage. The demand for cane products has dropped severely owing to the availability of cheaper alternatives made of plastic, forcing the male artisans to seek labour work in nearby towns and cities. In the recent past, however, with female artisans coming together to revive the dying handicraft, this age-old tradition has got a new 
lease of life, though there is still a long way to go ("Reviving an age-old tradition: Tynnai Handicraft"). The following lines reflect the poet's anguish at the marring of pristine environments:

\author{
Inevitably, however, here too, \\ time has left its ugly wounds \\ Pines like filth are lifted \\ from woodlands in truckloads. \\ Hills lose their summer green, \\ blasted into rocks, \\ into pebble and sand \\ and the sand is not spared. (36-43)
}

The poet is saddened by the mindless pursuits of the humans "who cannot think beyond possessions" (45), which makes him feel "softer, more poetic with this land and Kynshi" (48). At the same time, the poet portrays the river as a benevolent and persevering force of nature which despite all the damage continues to flow its regular course. Juxtaposed against the background of violence with which the state has lately become synonymous is the image of Nature symbolized by the rural oikos of the Kynshi valley and the simplicity of its inhabitants, that remains relatively unchanging and unperturbed as evident in these lines: "But Kynshi goes on, / however fickle the people,/however treacherous the customs" (49-51). Reverberating through the poem is the poet's voice of intervention and an urgent appeal to make concrete efforts to save the river from impending doom. The river and its ecosystem, in the words of the poet:
need to be preserved
in more than memories,
or the words of a backwater poet
ploughing clumsily through a foreign tongue. (14-17)

The mention of "words of a backwater poet" reinforces the poet's role as a witness and preserver of his traditions and cultural heritage. By doing so, he is able to revive his kinship with his community and bring about a reconstruction of their jeopardized identity. "Ren" (Nongkynrih18-19) is another poem that underscores the position of prominence nature occupies in the Khasi culture. The poem is based on an old Khasi legend that recounts the life of a fisherman, "the beloved of a river nymph (4)", who leaves behind his aging mother to "live in magic depths (7)" of the river in order to unite forever with his lover. However, 
before embarking on his underworld journey, he tells his mother "to listen to the river" (10) for its roar will be a proof of the continuity of her son's existence. By associating the flowing of the river with his own survival, the poem through this folklore establishes the river as the real source of the community's identity; it also shows the latter's dependence on the former for its very existence through the formulation of a unique consciousness and sensibility. The poem at the same time points out to the deplorable state of the river in modern times due to excessive urbanization of the region, thus simultaneously symbolizing the dying tribal identity and disorientation it has caused to the people.

In "The Ancient Rocks of Cherra" (Nongkynrih 84) the poet delves into mythology to underscore the drab realities of the present times. The origin of the ancient rocks of Cherrapunjee is linked with "the death throes of the Thlen, a gigantic man-eating serpent that once supposedly stalked its wilderness" (Nongkynrih 84). Despite its death, the curse of the mythical creature continues to haunt the region in the form of abject poverty and a struggle for subsistence, forcing its inhabitants to eke out living from "stones and caterpillars/ ... for out-of-town drunks / each market day" (4-6). By comparing the deep gorges of the region with "fiendish mouths/ yawning for desperate victims" (9-10), the poet accentuates the "incredible barrenness" (12) of the region that makes survival quite challenging and allows little respite for its inhabitants. The lines "This land is old, too old / and withered for life to be easy" (1-2) are suggestive of the extremely low level of agricultural productivity in these hilly regions due to the hostile terrain and severe dearth of resources. However, notwithstanding these issues, the poet's heart refuses to succumb to a state of absolute pessimism and despair as the "sight of dark grey rocks like sages / spells home ..."(15-16) to him, thus reinstating his faith in his mountainous country with which he finds his existence and identity linked inextricably. The reference to the origin myth can be read as the poet's endeavor to reaffirm his identity as being ancient and inseparably interwoven with the region.

"Identification Marks" (Nongkynrih 76-77) is a critique on the issue of identity, with its focus on the Khasi tribe of Meghalaya. The poem raises concerns about the authenticity of identities in contemporary times and exposes the futility of endeavors aimed at preserving the tribal culture. Cultural symbols are gradually losing their real significance and turning into objects of fetish ready to be consumed in the markets created by globalization. Oliver and Gershman, referring to the modern age and its impact on cultural symbols say, "It is an age in which the unconscious cultural symbols [...] are losing their vitality [...] and our connection with the natural living world is steadily decreasing" (Oliver and Gershman 2).The situation turns even more alarming when the indigenous people, the custodians of their culture, are severing their very roots and helplessly becoming victims of the invasion of their culture. The region's poverty, remoteness and underdevelopment aggravate this plight. Consequently, depravity seems to reign supreme as greed and cupidity get the better of the people, and they neglect and forget the cultural heritage that once 
nourished their souls in favor of lucrative pursuits that only incite their carnal hungers. The poem is written in a discursive manner and attempts to define the Khasi identity by suggesting numerous identity traits that were inherently associated with the Khasi tribe. Building on the argument, the poet in the second stanza employs a series of negative statements about what does not reflect being a Khasi and subsequently rejects them all. The last stanza resolves the complication using a series of sarcastic affirmative statements asserting what it does mean to be a Khasi, again mocking and ridiculing the symbolism that has replaced the traditional way of life.
A Khasi is a man, who once a year,
sports a muga-mulberry turban,
aneri ${ }^{5}$ shawl and is seen engrande tenue
at Weiking or Pomblang.
Who once a year, speaks of these great festivals
and the teachings of his great ancestors.
Who once a year, says
"to Know Man - to Know God,
to Know Maternal-Paternal Relations,
to Earn Righteousness" is our faith.
But this, only once a year. (22-32)

The poet deploys a series of ironical statements to expose the hypocrisy of the people who by falling prey to the modern ways have compromised their cultural wealth and true identity. Cultural symbols and traditions are remembered only on certain occasions for the sake of formality. Losing the cultural and traditional grounding adds to the identity crisis, although unthinkingly, people remain unaware of this problem. Besides, the poet laments the fading of symbols and attributes that once reflected the now-lost glory, valour and community pride of yesteryear. According to St-Hilaire:

... [In] consumption-oriented modernity, many cultures that are steeped in opposing or alternative values and forms of meaning tend to lose their place in local communities as esteemed and valid ways of being and doing. [...Consequently] associated systems of thought, cultural values, and ways of patterning human relations survive only partially intact, if at all ... In addition, in such cases young people often adopt and manage multiple, hybridized, or 
creolized identities, holding on to what they find valuable in their ancestral culture while integrating positive aspects of the larger, more socially appealing culture. (St-Hilaire 212)

A sprinkling of words from the native language further portrays the heterogeneity of the changing societies and cultures. In response to how often a Khasi associates with his cultural symbols, customs and traditions, the catchphrase "once a year" ridicules the superficial attempts made at identifying with one's cultural roots. "Self-actualisation" (Nongkynrih 105-107) is a humorous poem that describes the poet's attempts at defining his true identity. The poem employs sarcasm and irony to highlight the contradictory aspects of the poet's identity. It denotes the existence of paradoxical traits signifying heterogeneity that is innate in human nature and society at large. At the same time, it exposes the hypocritical, prejudiced and conservative attitudes prevalent in the society that give rise to narrow distinctions and hierarchies. The poet feels misunderstood and victimized by such limited perception though his intentions are sincere. The highlight of the poem is its utterly candid and confessional tone which the poet employs to lay bare his conscience:

How should I describe myself?

A son of a crab, since I fail to suffer

my mother's temper, who, living in my

house, treats me as one of her tenants.

An abusive husband, since I decline to be

tamed in a matrilineal arrangement.

A retrograde, since I want trees on the hills,

Birds in the woods, fishes in the streams.

A heathen, since I believe in sacred grove.

An atheist, since I am not a Christian.

A heretic, since I believe in the humanity

of my conscience. $(4-9,41-46)$

The poem harks back to the tribal traditions and beliefs that had kept the people thriving in sync with nature but which are now being lost to the detriment of all. Similarly, by using the expression "A recalcitrant Indian, since I am buried / too deep in my tribal roots and refuse to be / swept away by the Main Stream" (31-33) the poet reasserts his unique ethnic and tribal roots as the chief source from which he derives his 
sense of identity. At the same time, the expression also alludes to the attempts of the State at forcefully homogenizing and assimilating cultures and tribes that are unique, diverse and unwilling to compromise their identities. It is also his call for tolerance, empathy and understanding, whichare essential to accommodate disparate beliefs, values and ways of lives, especially in times when identities are threatened due to an overlapping and merging of various borders and boundaries.

\section{Conclusion}

Nongkynrih's poetry discusses several facets of identity such as the personal, social, religious, ethnic, cultural and political. Ethnic and cultural identities appear as the dominant theme in his poetry; he derives his sense of identity mainly from the 'collective identity' of his community, which includes the people, culture, customs, beliefs and nature. He feels strongly for preserving his cultural traditions, and laments that they are waning and losing ground in the modern times. His is a clarion call to his community to return to their cultural roots if the identity crisis has to be resolved. That one identity, remaining fixed, shall become an anchor for other identities to survive without conflict.

His poetry both underscores the woes that afflict the region and highlights the essence of the Khasi culture and its unique identity that is jeopardized in the modern times due to illegal immigration, army occupation, globalization, and political apathy,all of which have altered and disarranged the cultural and social order of the region. By creating awareness about its rich legacy and reworking an ancient heritage on the verge of extinction, the poetry serves as an instrument of vindicating a culture that has unfortunately become synonymous with violence, insurgency and turmoil. Nongkynrih's poetry, while representing the margin, endeavours to be empowering, and functions as "an enabling position from which mainstream structures can be contested" (Mahanta 109). Although the margins at times run the risk of turning into battlegrounds, various kinds of efforts are constantly being made to counteract the violence and insurgency.Poetry is one such potent instrument of peace in these troubled times which can abate the turbulence by restoring peace and sanity. Nongkynrih's poetry accomplishes this, as the paper has demonstrated, not by a mere assertion of his identity but by formulation of a new distinct consciousness and sensibility (Deleuze and Guattari “What Is a Minor Literature ?"17) in which the language opens to mutation and becomes "the vehicle for the creation of [a new] identity..." (Colebrook104). Unlike the major literature, where the content antecedes the expression (Deleuze and Guattari "Kafka"85), Nongkynrih's poetics is characterized by its complete disregard for the conventional content which it deliberately breaks down in order to reassemble and reconstruct new forms and expressions. Thus, owing to its politically charged sensibility, a firm rootedness in the tradition, minoritarian stance and disregard for 'mainstream' poetics, Nongkynrih's poetry is apt to be regarded as a minor literature as well as counter-culture. 


\section{Notes}

${ }^{1}$ The Austro-Asiatic language of the Khasi people.

${ }^{2}$ The Mon-Khmer language of the Khasi people.

${ }^{3}$ An Arabic word which means Islamic call to prayer.

${ }^{4}$ Tynnai is a small village that comprises eighty six households and is located in South West Khasi Hills District of Meghalaya.

${ }^{5}$ The name "eri" is derived from the Assamese word "era", which means "castor", as the silkworm feeds on castor plants.

\section{Works Cited}

Bhabha, Homi.The Location of Culture. Routledge, 2004.

Bhatnagar, G. "The tribal festivals of Meghalaya." Times Travel, https://timesofindia.indiatimes.com/travel/things-to-do/The-tribal-festivals-of $\underline{\text { Meghalaya/as51790995.cms, }}$ April 14, 2016. Accessed 20 May, 2020.

Bhattacharjee, Subashish, and Sahikat Guha. "Towards a Poetics of Reconstruction: Reading and Enacting Identity in Kynpham Sing Nongkynrih's Poetry.” Abstract. Rupkatha Journal, vol.6, no. 2, 2014, pp. 8394.

Brass, Paul R. Ethnicity and Nationalism: Theory and Comparison, New Delhi: Sage Publications, 1991.

Cohen, Erik. "Authenticity and Commoditization in Tourism." Annals of Tourism Research, vol. 15, no. 3, 1988, pp. 371-386, https://doi.org/10.1016/0160-7383(88)90028-X. Accessed 30 Jan. 2019.

Colebrook, C. Gilles Deleuze. London, England: Routledge, 2002.

Das, Prasanta. "Anthology-Making, the Nation, and Shillong Poets." Economic and Political Weekly, vol. 43, no. 42. 2008. pp. 19-21. 
Deleuze, Gilles, Félix Guattari, and Robert Brinkley. “What Is a Minor Literature?” Mississippi Review, vol. 11, no. 3, 1983, pp. 13-33. www.jstor.org/stable/20133921. Accessed 15 Feb. 2019.

Deleuze, G. and Guattari, F. Kafka: Toward a Minor Literature. (Dana Polan, Trans.). Minneapolis, MN: University of Minnesota Press, 1989.

Dutta, Urmitapa. “The Long Way Home: The Vicissitudes of Belonging and Otherness in Northeast India." Qualitative Inquiry, vol. 21, 2015, pp. 161-172.

Greenwood, Davydd J. "Culture by the Pound: An Anthropological Perspective on Tourism as Cultural Commoditization.” Tourism Alternatives: Potential and Problems in the Development of Tourism, edited by V. Smith and W. Eadington, University of Pennsylvania, 1977, pp. 129-138.

Hussain, Wasbir. "Contemporary North-East India: Problems and Prospects." Trends in Social Sciences and Humanities in North East India, 1947-97, edited by J.P. Singh et al., Regency Publications, 1998, pp. 126-134.

"Festivals and Ceremonies of the 'Khasis."” Department of Arts and Culture, Government of Meghalaya, http://megartsculture.gov.in/festivals-khasi.htm, n.d. Accessed 20 May, 2020.

Kobena, Mercer. Welcome to the Jungle: New Positions in Black Cultural Studies. Routledge, 1994.

Mahanta, Namrata R. "Women Novelists in English from the North-East: A Contemporary Perspective." The Indian English Novel of the New Millennium, edited by Prabhat K. Singh, Cambridge Scholars Publishing, 2013, pp. 105-113.

Mukhim, Patricia. "Conflict and its Resolution: A Case Study of a Modern Tribal Situation." Ethnicity, Culture and Nationalism in North-East India, edited by M.M. Agrawal, Indus Publishing Company, 1996, pp. 38-48.

Ngangom, Robin S. and Nongkynrih, Kynpham S. "Editors' note.” Anthology of Contemporary Poetry from the Northeast, edited by Robin Singh Ngangom and Kynpham Sing Nongkynrih, NEHU Publications, 2009, pp. ix-X. 
Ngangom, Robin S. and Nongkynrih, Kynpham S. "Introduction.” Dancing Earth: An Anthology of Poetry from North-East India, edited by Robin Singh Ngangom and Kynpham Sing Nongkynrih, Penguin Books India Pvt. Ltd., 2009, pp. ix-xv.

Nongkynrih, Kynpham S. The Yearning of Seeds, HarperCollins Publishers, 2011.

Nuh, V.K. "The Cry of the Naga." Peace in India's North-East: Meaning, Metaphor, and Method: Essays of Concern and Commitment, edited by Prasenjit Biswas and C. Joshua Thomas, Regency Publications, 2006, pp. 133-154.

Oliver, Donald W., and Kathleen Waldron Gershman. Education, Modernity, and Fractured Meaning: Towards a Process Theory of Teaching and Learning. State University of New York Press, 1989.

Pakem, B. "Inaugural Address." Ethnicity, Culture and Nationalism in North-East India, edited by M.M. Agrawal, Indus Publishing Company, 1996, pp. 11-20.

Pelly, Grace, and Jai Singh. State terrorism: torture, extra-judicial killings, and forced disappearances in India: report of the Independent People's Tribunal, 9-10 February 2008. Human Rights Law Network, 2009.

Phanjoubam, P. "Northeast Problems as a Subject and Object." Beyond Counter-Insurgency: Breaking the Impasse in North-East India, edited by Sanjib Baruah, Oxford: Oxford University Press, 2009, pp. 147169.

Prabhakra, M. S. “Is North-East India Landlocked?” Economic and Political Weekly, vol. 39, no. 42, 2004, pp. 4606-4608. JSTOR, www.jstor.org/stable/4415670.

"Reviving an age-old tradition: Tynnai Handicraft." Meghalaya Basin Development Authority, https://mbda.gov.in/reviving-age-old-tradition-tynnai-handicraft, n.d. Accessed 19 May, 2020.

Robins, K. "Identity". New Keywords: A Revised Vocabulary of Culture and Society, edited by T. Bennett, L. Grossberg and M. Morris, Malden, Blackwell, 2005, pp.179-181. 
Rusen, Jorn. "Tradition and Identity: Theoretical Reflections and the European Example." Taiwan Journal of East Asia Studies, vol. 1, no. 2, 2004, pp. 135-158.

Singh, A.M. "A Study on Illegal Immigration into North-East India: The Case of Nagaland." Institute for Defence Studies and Analyses, vol. 8, 2009. pp.1-56

Singh, B.P. The Problem of Change: A Study of North East India. Oxford University Press, 1996.

St-Hilaire, Aonghas. Kwéyòl in Postcolonial Saint Lucia: Globalization, Language Planning, and National Development. John Benjamins Pub.2011.

Tunyi, Zhoto and Wouters Jelle J.P. “India's Northeast as an Internal Borderland: Domestic Borders, Regimes of Taxation, and Legal Landscapes.” The NEHU Journal, vol. XIV, no. 1, January - June 2016, pp. 1-17.

Van Schendel, W. "The Dangers of Belonging: Tribes, Indigenous Peoples and Homelands in South Asia." The Politics of Belonging in India: Becoming Adivasi, edited by D.J. Rycroft and S. Dasgupta, London and New York: Routledge, 2011, pp. 19-43.

Zariski, Raphael. "Ethnic Extremism among Ethnoterritorial Minorities in Western Europe: Dimensions, Causes and Institutional Responses.”Comparative Politics, vol.21, no.3, 1989. pp. 253-272. 